https://helda.helsinki.fi

\title{
The Finnish Design of Folk High School Education
}

\section{Partanen, Pirkko}

2013

Partanen , P , Ruokonen , I \& Ruismäki , H 2013 , ' The Finnish Design of Folk High School

Education ' , The European Journal of Social \& Behavioural Sciences , vol. 7 , pp.

1180-1186 . https://doi.org/10.15405/ejsbs.97

http://hdl.handle.net/10138/233042

https://doi.org/10.15405/ejsbs.97

cc_by_nc_nd

publishedVersion

Downloaded from Helda, University of Helsinki institutional repository.

This is an electronic reprint of the original article.

This reprint may differ from the original in pagination and typographic detail.

Please cite the original version. 


\title{
The European Journal of Social \& Behavioural Sciences (EJSBS)

\section{The European Journal of Social \& Behavioural Sciences (eISSN: 2301-2218)}

\section{The Finnish Design of Folk High School Education}

\author{
Pirkko Partanen $^{\mathrm{a} *}$, Inkeri Ruokonen ${ }^{\mathrm{a}} \&$ Heikki Ruismäki ${ }^{\mathrm{a}}$ \\ ${ }^{a}$ Department of Teacher Education, University of Helsinki
}

http://dx.doi.org/10.15405/ejsbs.97

\begin{abstract}
In Finland, folk high school education began in 1889 and consisted of non-formal adult education in Finland. The aim of the study is to research the role of folk high school education into Finnish culture. The study introduces the history of Finnish folk high school education and discusses the role of folk high school education in the Finnish educational system, especially arts education. The purpose is to determine which developmental stages can be found in the history of Finnish folk high school education, and what role Finnish folk high school education played in the development of Finnish culture and arts education. The study approach is a historical-critical overview of the period from 1889 to 2012. Historical documents, archives and articles are content analysed to discover the trends influencing folk high school education, Finnish culture, and the arts in different time periods. The results show that Finnish folk high school education played a strong role in Finnish culture, especially in the education of people in rural areas. The influence on teachers' education was found in both basic level and advanced education. The role of arts education, especially music education has been strong since 1970. The role and influence of Finnish folk high school education has been strong in Finnish society because it has been able to change and develop over time. Finnish folk high school education design has had a creative influence on the Finnish culture.
\end{abstract}

(C) 2013 Published by C-crcs. Peer-review under responsibility of Editor or Guest Editor of the EJSBS.

Keywords: Folk high school institution, Finnish education system, history of adult education, arts education

\section{Introduction}

Folk high school institutions have a long and special history in the Finnish educational system. The ideas of the father of folk high schools, Danish theologian, poet and philosopher Nikolaj Frederik Severin Grundtvig were well known and suitable for the Finnish folk high school. Folk high schools were founded for the youth; "the living

\section{* PhD Pirkko Partanen}

E-mail address: partanen.pirkko@ saunalahti.fi

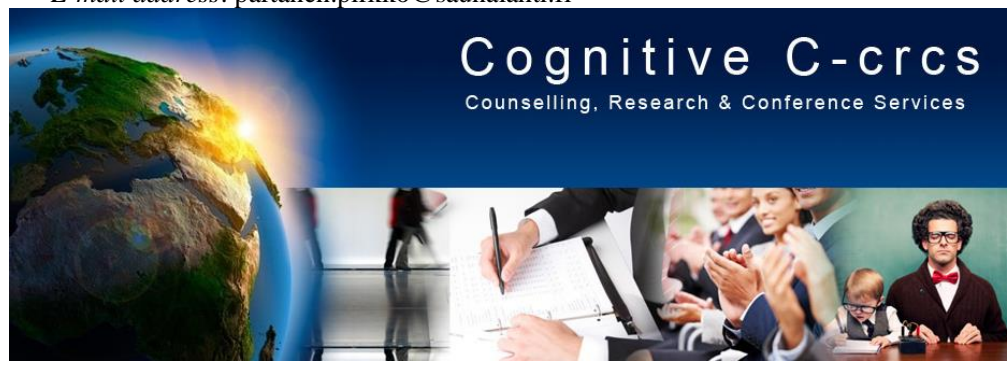


word" was a key concept and awakening a human being as well as offering schooling for broad groups of people was the aim. In the beginning, folk high schools were residential and today most of them remaining so. They are still a good place to orientate to the future by creating new ideas for free and open learning.

\section{Research Problems and Methodological approach}

The aim of the study is to research the role of folk high school education to Finnish culture. The study introduces the history of Finnish folk high school education and discusses the role of folk high school education in Finnish educational system, especially arts education. The research problems are:

1. Which developmental stages can be found in the history of Finnish folk high school education and

2. What role did Finnish folk high school education play in the development of Finnish culture and arts education?

The approach of this article is a historical-critical overview of period 1889-2012. According to Kuikka (2001) and Brickman (1975), an educational history researcher needs to focus on a given topic, consider the availability of sources, allow for a suitable amount of time for the study and be aware of any special knowledge needed for the study. In this article special knowledge includes the earlier research by Partanen (2009a) and Ruismäki \& Ruokonen (2006) concerning educational system of Finland and folk high schools and arts education.

Historical research on education relies on social and pedagogical research traditions. The historical, critical approach interpreter tries to understand both the historical situation to which the text points and the historical situation of the author. Sometimes these are the same, but often they are not.

Elliot (2002) writes about post-positivism is a concept that views knowledge as conjectural, therefore, different evidence (documents, questionnaires, interviews, etc.) is used to arrive at the final solutions of the research problem. A researcher's decisions and understanding are required to determine the most important historical acts in education at the given time and place, which rely on as much relevant evidence and as many sources as possible. This critical approach in post-positivistic thinking can lead to the best possible understanding, which develops in the process of seeking the "perfect truth" (Elliott 2002).

This research consists of historical documents, archives and articles concerning Finnish Folk High Schools during period from 1889 to 2012. It was content analysed to discover the influence that folk high school education had on Finnish culture and the arts in different periods.

The first folk high school in Finland was founded in 1889. Over 120 years, many activities have changed, but the arts have had an essential role since the beginning. Folk high schools are a part of liberal adult education and receive government subsidy. Students pay for full board and some teaching because the subsidy is not sufficient to cover all the costs.

Folk high school is an educational institution offering a broad range of education for adults. As residential schools, folk high schools foster a sense of community, which forms part of the all-round learning experience and functions as a cornerstone of the education process. The folk high schools of today offer a viable alternative, to help individuals fulfill their potential, and to help them to become more aware, critical and responsible members of society. (Finnish Folk High School Association, 2013)

In the Finnish educational system, the role of the folk high schools is to provide adult education and liberal adult education. The courses offered are mainly general or non-formal but initial and further vocational training is also offered. There are about 90 folk high schools all over Finland. Most of them are owned by private ideological organizations, foundations or corporations. Legislation has granted them far-reaching autonomy and freedom. A majority of them teach in Finnish, with less than 20 teaching in Swedish. (Finnish Folk High School Association, 2013)

Teaching on the school year running long courses tends to concentrate on social sciences and humanities subjects, art and languages. There has also been a great increase in the number of short courses offered by folk high schools. Most of the short courses are held in the summer, so folk high schools generally have activities taking place year-round. Short courses have been a good choice for summer holidays and teachers have used these opportunities 
to reinforce their skills such areas as music (Partanen 2009b). The contents of the short courses are similar to the long courses. A majority of folk high schools now also offer Open university courses with many more being offered each year. The size of a folk high school can vary widely: the largest folk high schools have about 450 students on long courses each year, while the smallest ones have about 30-40. (Kansanopistot 2012.)

\section{History of folk high schools}

The folk high school as an educational institution is a special one. The first institute was founded in Denmark in 1844. Very soon Norway founded its first folk high school. Later Sweden started such institutions as well. Last but not least they began in Finland in 1889. For Finland the new institution has been important especially during hard times. A national awakening among folk was aroused during Russification from 1890s and during periods of oppression (1899-1905 and 1909-1917). During and after the Second World War especially Christian folk high schools were founded. Nowadays there are folk high schools in many countries all over the world. The father of the folk high school is Danish theologian, poet and philosopher Nikolaj Frederik Severin Grundtvig (1783-1872). His main idea was that the folk high school would be a school for the youth, because young people easily adopt influences. Furthermore, he thought that the folk high school would be a school of "the living word". The personality of teachers had to be inspirational and rousing. Interaction between teachers and pupils was essential. He believed that the folk high school must be also an awakening school where the spiritual forces of the youth are opened and expanded. Grundtvig hoped that the folk high school would be popular (folkelig); its task was to be available to broad groups of people. These ideas and tasks were acquired in all the Nordic countries. Though Grundtvig was a theologian, he said that it is necessary to awaken a human being before a Christian. (Karttunen 1979, 9; Kauppila 2007, 64.) In fact, Grundtvig's ideas were very modern. Kauppila $(2007,64-67)$ has said that Grundtvig's ideas were near to those of socio-constructivism, one of the main learning theories today.

In Finland, the students' associations became enthusiastic about the idea of the folk high school. University students with an agricultural background especially subscribed to these ideas. Kansanvalistusseura, The Finnish Lifelong Learning Foundation with ideological roots in national and cultural awakening published these ideas extensively. Finland was in many ways backward and poor. It was a Grand Duchy and an autonomous part of Russian empire. When Russification began in 1890 many folk high schools were founded. Artists and composers contributed their work. For instance, Sibelius composed the Karelia suite to raise funds for the folk high school in Uusikirkko in 1893. (Partanen 2009a.)

After 1907, this type of fundraising was no longer necessary as the Parliament started to give government subsidy to these schools. Curriculums were free and schools had different orientations. The students in the folk high schools came from the rural areas. At the beginning and even in the 1940s and 1950s, many of young students had very little previous schooling. During the first decades even every third student had studied only part of elementary school or had no schooling at all. In 1921, the government act of common, compulsory education come into effect. Later on, the schools were also important. For example, after the Second World War, there were students that had only had minima studies in the elementary school, because the schools were shut for long periods during the war (Kuikka 1991).

Humanistic and societal subjects were the focus, but arts in different forms were also common. In many folk high schools practical subjects like home economics, agriculture and crafts were also taught. It has been said, that folk high schools were singing schools. Lessons began and ended with a song. Both guests' reception and farewell ceremonies involved singing. Statistics from the National Board of Education from 1905-1906, show that there was singing on average of three lessons weekly. Singing was seen as an important source of togetherness. The first folk high schools were "Grundtvigian". In these schools both secular and religious songs were sung. They were patriotic, provincial and folk songs. Many folk high school songs from the other Nordic countries were translated into Finnish. (Karttunen 1979, 39-40.) In some schools students were trained to play instruments. The first Christian folk high school was founded in 1907. In these schools only religious music was sung, psalms and other religious music was a part of these schools as late as the 1930s (Karttunen 1979, 182).

As schools were residential and students stayed at the schools also during the weekends, many activities were possible during free time. Artistic activities like drama and choir singing were popular. Evening parties with various 
programs were held. Peers also commented on these programmes. One can get a conception of the wideness of choir singing among students from the story of the 50th anniversary of Finnish folk high schools in 1939. One thousand Finnish-speaking students were singing a choir program at the main festival in the Helsinki exhibition hall (Messuhalli). The Swedish- speaking students had their own choir at the same ceremony and the choir of Christian folk high schools also performed at a festival service at Johannes Church. There were 3,000 students at these festivals along with 300 teachers. (Karttunen 1979, 182-183.)

Before the Second World War in Finland there were 63 folk high schools, 47 Finnish-speaking and 16 Swedishspeaking (Karttunen 1979, 206). During and after the Second World War in Finland mostly Christian and societal folk high schools were founded (Karttunen 1979, 206). Today in Finland there are 90 folk high schools. There are 44 Christian, 33 independent, 10 societal and 3 special folk high schools. Most of them are private. All receive statutory state subsidy and they are supervised by the authorities (Kansanopistoyhdistys 2008).

Many changes have occurred during the past 120 years, but folk high schools maintained their previous practices up to the 1950s. High idealistic values where placed on home, religion and patriotism. To grow as a human being and live as if at home with many household duties in the kitchen was the axiom. Teachers and students had warm interaction from the beginning up to mid-twentieth century. Teachers had their homes on the school campus and participated in students' life. They were not only teachers, but also like mothers and fathers to the students. The working days ran from seven o'clock in the morning to nine o'clock in the evening. However, the school year was short, it run from October to April because most students came from farms and had to return to their duties there. (Issakainen 2005, 26.)

Many folk high schools incorporated the programme called University of the People during the second school year. This two-year schooling was in a way alternative for secondary schools and opened doors to vocational studies for certain students. For instance, the folk high school of Orivesi had a joint work programme with the Societal High School. Many communal directors and secretaries had their early schooling at the Orivesi folk high school. Students received points also to elementary teacher training schools, called seminars. After seminar education according to Partanen (2009b), the Klemetti Institute, a part of the folk high school of Orivesi promoted Finnish music culture and played an important role in the continuing music education of primary school teachers.

It is said that fifties and sixties were golden age of this two-year schooling (Ojanen, 2010, 143). At that time, the secondary school net was still thin and especially youth in rural areas did not often have an opportunity possibility for schooling. The second school year was finished in 1984, when it was no more need for this schooling. Up to 1970s there was a collateral system in Finnish schooling. Children began elementary school at the age of seven. At the age of ten, they could strive for secondary school or go through the elementary school. Elementary school had seven classes. Secondary school had two levels, lower-secondary school and upper-secondary school with written matriculation examinations. In the 1970s, major changes in the education system fused elementary school and lower-secondary school to nine class lasting basic education in comprehensive schools. During the period of transition, folk high schools had a prominent role in administering final examination in basic education. So they remained a part of the education structure. Today $7 \%$ of the students in folk high schools are part of this basic educational schooling.

\section{Folk high schools to-day}

Major structural and social changes took place in the 1960s in all of Finnish society and affected the future of folk high schools. Because the legislation granted folk high schools far-reaching autonomy and freedom, many different curricula were developed in different folk high schools and continue to this day. Flexibility and freedom to arrange curriculum have enabled the development of folk high schools. Today there are five different sectors: nonformal adult education $(60 \%)$, basic education $(7 \%)$, general upper-secondary education $(6 \%)$, vocational basic education $(18 \%)$ and vocational added education $(8 \%)$. Folk high schools have also served immigrants. About 20 $\%$ students in non-formal adult education are immigrants. Folk high schools are a mixed model of schooling. No 
matter which format they take, they all follow in every sector the Acts of Parliament. (Finnish Folk High School Association, 2012.)

Non-formal education in folk high schools covers many subjects and courses, although many folk high schools have specialized in the arts. About 50 schools have emphasized arts: visual arts, dance, drama in many forms and music from classical music to gospel and rock. The variety arts courses means that there are many different kinds of products. Many of these programmes prepare students for a future vocation. The long courses extend from September to May, but it is possible to begin later during the school year. In some schools, students can take a programme for two years or even more. As residential schools, folk high schools foster a sense of community. The music training program has 19 folk high schools and visual arts in different forms in 23 folk high schools.

Folk high school education takes many forms, especially today. In addition to arts education, education for different vocations, such as vocational qualifications for data processing and school assistant are also arranged. Another important area is Internet teaching. One can study both basic and secondary studies through the Internet. (Studies of Finnish Folk High Schools 2013.) Now with great cuts in statutory state subsidy, folk high schools are in trouble. It is possible that some folk high schools close. Some others try to get new programs and even move from rural to urban areas to broaden their scope.

\section{Folk high schools as a route to university}

Nowadays more and more students come to folk high schools after their matriculation examination, that's why Open University courses are popular. (Virtanen \& Kärkkäinen 2006.) In Finland one can start university studies in the Open University. For instance in Orivesi one can study literature up to 50 points and writing also to 50 points. Most common in folk high schools are studies at basic courses of 25 credit points ( 1 credit point $=27$ hours).

There are no statistics available about studies after folk high school. One survey was made for students, who had studied in four different kinds of folk high schools. The response per cent was not sufficient, only $22 \%$, but it gave some interesting outcomes. More than $80 \%$ had taken the matriculation examination. Folk high schools received a more positive estimation than general upper secondary school. The freedom, variety, independence and academic nature of the schools were especially appreciated. Most of students had studied Open University courses. After studying in folk high schools, more than half of the students gravitated to universities and $80 \%$ were admitted on the first or second attempt. (Kinnunen 2008, 3, 58.)

For this article the actual information was gathered from 20 arts based folk high schools by using questionnaire. according to the results the range among the schools was wide. From some schools almost all students gravitated to universities or polytechnics, but there were schools without any students who pursued later studies. In these schools, art courses were followed for therapeutic purposes without a vocational goal. In some other high schools estimation is from 30 to 50 per cent. The Secretary General of Finnish Folk High School Association, Jyrki Ijäs (2013) emphasizes expertise of teachers. According to him only professional artists can give the best possible teaching in art. Today $50 \%$ of vocational visual artists have had a folk high school background. According to Päivi Lassheikki (2013) from the folk high school of Lahti approximately 70-95\% of students continue their studies to universities, polytechnics or vocational studies in a cultural field. Figure 1 shows the roles of the folk high school to the Finnish culture and arts education.

\section{Conclusions}

Folk high schools in Finland have had their difficulties. The freedom to arrange teaching has meant that teachers could be innovative. Arts in different forms have been saved in many folk high schools. Many people want to study arts, but not all have had the opportunity to study arts seriously as children and youngsters. Thus, folk high schools are good places to prepare for an art vocation. For many people folk high schools can mean a time to become independent because in many folk high schools there are several art lines, co-operation between them allows integration and innovation. Nowadays more and more free education is also directed to the elderly people in folk high schools. 


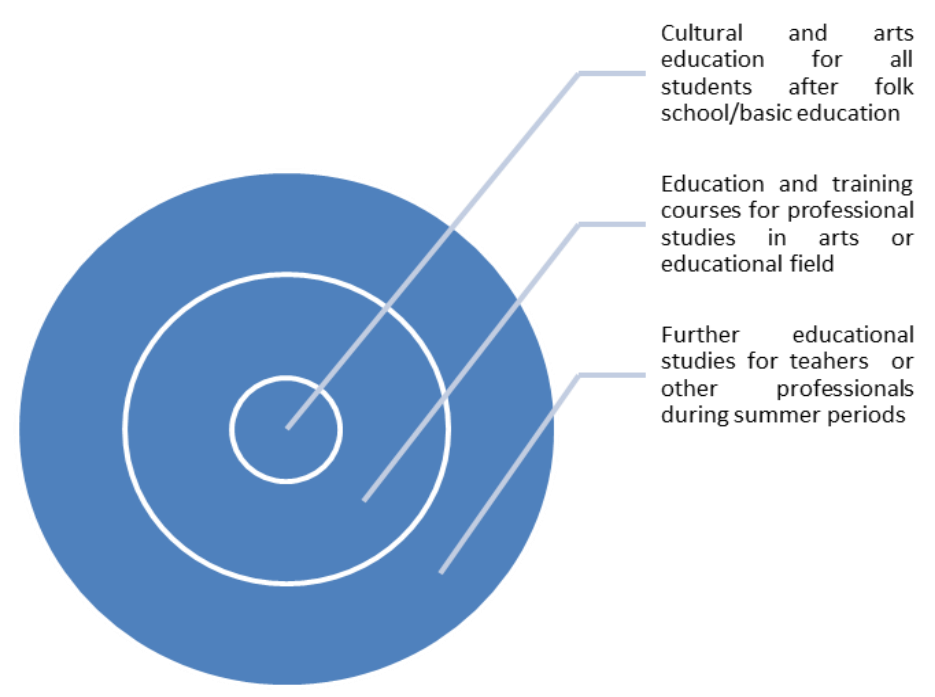

Fig. 1. The Roles of Folk High School to the Finnish culture and arts education

The results show that Finnish folk high school education has a strong role in Finnish culture, especially in the education of those in rural areas. The influence on the teachers' education was found in both basic level and further education. The role of the arts education has been strong after 1970. The role and influence of Finnish folk high school education has been strong in a Finnish society because it has been able to change and develop over the times. Finnish folk high school education design has had a creative influence to the Finnish culture.

\section{References}

Brickman, W.W. (1975). Research in educational history. Norwood: Folcroft Library Editions.

Elliott, D.J. (2002). Philosophical perspectives on research. In R. Colwell \& C.

Richardson (eds.), The New Handbook of research on music Teaching and learning (pp.85-102).

Oxford: Oxford University Press.

Finnish Folk High School Association (2012). Finnish Folk High School Association's Member Meeting Document. Orivesi: Finnish Folk High School Association. Home pages of folk high schools in Finland. http://www.kansanopistot.fi/

Ijäs, J. (2013). Interview 15.4.2013.

Issakainen, T. (2005). Kansanopistot sisäoppilaitoksina. In Kansanopisto Journal 4/2005 (pp.23-29). Orivesi:

Finnish Folk High School Association (2013). Kansanopistot. [Folk High Schools]. http://www.kansanopistot.fi/ (read 23.4.2013)

Kansanopistoyhdistys (2008). Suomen kansanopistot. [Finnish Folk High Schools]. http://sivistys.net/yhteistyokumppanit/suomen_kansanopistoyhdistys (read 2.11.2012).

Kansanopistot. (2012). Opinnot. http://www.kansanopistot.fi/opinnot/studies.html_(read 1.11.2012)

Karttunen, M. O. (1979). Suomen kansanopisto 1889-1979. [Finnish Folk High School 1989-1979]. Forssa: Suomen Kansanopistoyhdistys.

Kauppila, E.A. (2007). Ihmisen tapa oppia. [Human's way of learning]. Juva: PS-kustannus.

Kinnunen, K. (2008). Kansanopistot väylänä korkeakouluun. [Folk high schools as a route to university]. Espoo: Työväen Akatemia.

Kuikka, M. (1991). Suomalaisen koulutuksen vaiheet. [The history of Finnish education]. Keuruu: Otava.

Kuikka, M. (2001). Kasvatuksen historian tutkimus. [Research of Educational History]. Helsinki: Otava. 
Lassheikki, P. (2013). Interview 17.4.2013.

Ojanen, E. (2010). Asuuko henki lammessa? Oriveden Opisto 1909-2009. [Is the spirit living in the pond? High school of Orivesi 1909-2009]. Keuruu: Kansanvalistusseura.

Partanen, P. (2009a) Arts as an educator of the folk. In Arts-Contact Points Between Cultures. 1st International Journal of Intercultural Arts Education Conference: Post-Conference Book (pp.45-52, eds. H. Ruismäki \& I. Ruokonen). University of Helsinki. Research Report 312. Helsinki: University Press.

Partanen, P. (2009b). Koko talo soi: Klemetti-Opisto suomalaisen musiikkikulttuurin kehittäjänä 1953-1968. ["The house is filled with music": The Klemetti Institute as a developer of Finnish music culture from1953 to 1968]. Research Report 310. Department of Applied Sciences of Education. Faculty of Behavioural Sciences. University of Helsinki. Helsinki: University Press.

Ruismäki, H. \& Ruokonen, I. (2006). Roots, current trends and future challenges in Finnish school music education. In A.Juvonen \& M. Anttila (Eds.). Challenges and visions in school music education: focusing on Finnish, Estonian, Latvian and Lithuanian music education realities. (pp.31-76). University of Joensuu. Bulletins of the faculty of education n:o 100. Joensuu: University Press.

Studies of Finnish Folk High Schools (2013). Study in Folk High School. Studies of Finnish Folk High Schools 2013-2014. Orivesi: Finnish Folk High School Association.

Virtanen, S. \& Kärkkäinen, L. (Eds.) (2006). Opiskele kansanopistossa. Folkhögskolestudier. Opinnot 20062007. [Study in Folk High School. Studies 2006-2007]. Helsinki.: Suomen Kansanopistoyhdistys - Finlands Folkhögskol-förening ry. 